\title{
Mental Yoga in the Correction of Chronic Cholestasis
}

\author{
Shaposhnikov Veniamin Ivanovich* \\ Kuban Medical Institute, Professor of Surgical Diseases, Russia
}

Submission: February 27, 2019; Published: April 10, 2019

*Corresponding author: Shaposhnikov Veniamin Ivanovich, Kuban Medical Institute, Professor of Surgical Diseases, Vice Rector, Krasnodar, Russia

\begin{abstract}
The author describes the causes of chronic cholestasis and ways of correction. Reflects the importance of mental yoga in this process because conventional treatments are ineffective and may even lead to dangerous complications. Psychic same Yoga eliminates dominant and in conjunction with a balanced diet, and mechanical impact on the irrigative bowel normalizing stool.
\end{abstract}

Keywords: Chronic cholestasis; Mental yoga; Correction

\section{Introduction}

Among the diseases of mankind chronic cholestasis is one of the main places. In animals it is not observed, because they have no morals, and they commit the Act of defecating where horrible and at first. In humans the same morality is formed in early childhood, and basically the next of kin. In the future, it could lead to the development of their cholestasis. The fact of the matter is that children do not have time in the morning to commit an act of defecation, suppress it, and go to kindergarten, school, and then at the universities, with a packed bowel. Something similar can happen at any age. So, people are hosted to form a dominant on constipation, i.e. create a temporarily ruling hotbed of excitation in the central nervous system, which accumulates in itself some kind of excitement, suppressing the work of other centers. The main features of it is this anxiety, ability with firmness to hold institution, summed up in the excitation itself from consistently come nerve impulses [1,2]. So, every year, increasing koprostaza. Toxic breakdown products of food not only poison the organism, but also cause severe disease, including cancer. Proctologist in his works notes that exceptional harm for health chronic cholestasis [3-5]. They provide recommendations for treatment, but there is no information about the significance of this issue of psychogenic factor of Yoga [6-8]. However, without applying it fully repay dominant in the central nervous system at koprostaz. This requires mental auto training, which experts recommend yoga. It allows not only control the feelings, but also to relax and restore normal motor function of the bowel, which is the decisive factor in the correction of cholestasis. In this situation, a typical set of asanas is contraindicated, because exercise can increase the pain in the abdomen, but massage the abdomen, especially on a course of colon, is useful. On the motor activity of the gastrointestinal tract can be influenced and nutritionsufficient intake of plant fiber. Meditate in the morning, but many recommend at this time rushing working, and then these need to be addressed before bedtime. With the integrated application of all these treatments, through 2-3 of the months you can normalize motor function of the intestine.

\section{Material and Methods}

Questionnaires 100 students of Medical University showed that $100 \%$ of them suffer from a lack of chairs from 2 to 3 days. To achieve the defecation, they resort, to cleaning enemas, then to take laxatives. Phenomena of the same chronic constipation have developed from them even during his school years. These activities for the correction of constipation, they felt comfortable and harmless, and information about their dangers is greeted with apparent confusion of feelings. I had to explain to them that when enemas happen skid putrefactive flora from the anus of the channel in sigmoidin gut, and it leads to the development of nonspecific ulcerative colitis and in laxatives, there has been a big loss of albumin and from this suffering immunity. Questionnaire survey conducted among students of Senior courses and this greatly simplified understanding of information. They were recommended by the mental basics of Yoga master via the Internet. Contact massage belly starting from the right iliac region and ending at the left. The duration of these manipulations should be from 10 to 20 minutes, and then they need to be in the evening on an empty stomach. Then take food rich in vegetal fiber. In the morning the same drink 2 cups of cool boiled water and tend to defecate was accomplished in a few minutes, and then be sure to perform hygiene activities. 


\section{The Results of the Study}

Repeated questioning over 2 months showed that all students learn to meditate, and more violations of defecation is not affected. They have improved performance and diligence in their studies. Improved mood.

\section{Discussion}

On Chronic koprostaz which arose even in childhood and requires correction because it is not only functional, but also violations of diseases. Toxic products of metabolism poison and fecal mass, taken away skopljajushchiesja in the rectum are men and chronic prostatitis. The usual means of treatment may not give the desired effect, so as not to destroy the dominant in the cortex. In such cases, only with the aid of mental Yoga you can achieve the effect. In this we have seen on the example of medical students of the University who have been identified, and then eliminated chronic cholestasis. It benefited from their academic progress and other human qualities.

\section{Conclusion}

Mental Yoga is an effective method to suppress temporarily the dominant lesion in the central nervous system excitation, which accumulates in itself some kind of excitement, suppressing the work of other centers. The main features of it is this anxiety and ability to firmly hold it, and then summed up in yourself from incoming consistently excitation of nerve impulses. Dominant every year reinforces their negative effects on the body. It is clearly observed and developing chronic cholestasis. And for this reason, it requires a correction to the complex of medical actions, of which the leading value is given to mental yoga.

\section{References}

1. Golovin S (1998) Dictionary of practical psychologist, Minsk -182.

2. Zinchenko VP, Meshcheryakov BG (2002) Big psychological dictionary. $\left(3^{\text {th }}\right.$ edn), p. 306.

3. Aminev AM (1971) Guide to proctology. Kuibyshev book volume 2.

4. Vorobows GI, Shelygin YA, Blagodarnii LA, Hemorrhoids M (2002) 192 $\mathrm{n}$.

5. Armstrong DN, Ambrose WI, Schertzer ME (2002) Harmonic scalpel hemorrhoidectomy. Dis Colon Rectum 45: 354-359.

6. Zarodnjuk IV, Tihonov AA, Titov AY, Mudrov AA (2004) Defecography in patients with defecation disorders survey. Coloproctology 2(8): 4550.

7. Bayer I, Myslovaty B, Picovsky BM (1996) Rubber band ligation of hemorrhoids. Convenient and economic treatment. J Clin Gastroenterology 23(1): 50-52.

8. Garvenda M, Wolter I (1996) Surgical therapy of advanced haemorrhoidal disease: is an ambulatory surgery intervention possible? Chirurg 67(9): 940-943.

Your next submission with Juniper Publishers
will reach you the below assets
- Quality Editorial service
- Swift Peer Review
- Reprints availability
- E-prints Service
- Manuscript Podcast for convenient understanding
- Global attainment for your research
- Manuscript accessibility in different formats
( Pdf, E-pub, Full Text, Audio)
- Unceasing customer service
Track the below URL for one-step submission
https://juniperpublishers.com/online-submission.php

